\title{
TRACE METAL ASSESSMENT OF RIVER KUBANNI, NORTHERN NIGERIA
}

\author{
UZAIRU, A. ${ }^{1}$; HARRISON, G.F.S. ; ; BALARABE, M.L. ${ }^{2}$ \& NNAJI, J.C. ${ }^{3}$ \\ 1 Department of Chemistry, Ahmadu Bello University, Zaria, Nigeria \\ 2 Department of Biological Sciences, Ahmadu Bello University, Zaria, Nigeria \\ ${ }^{3}$ National Institute for Freshwater Fisheries Research, P. M. B. 6006, \\ New-Bussa, Niger State, Nigeria \\ ${ }^{3}$ Corresponding author - Nnaji, J. C; e-mail, dozis03@yahoo.com
}

\begin{abstract}
Uzairu, A.; Harrison, G.F.S.; Balarabe, M.L. \& Nnaji, J.C. 2008. Trace metal assessment of river Kubanni, northern Nigeria. Braz. J. Aquat. Sci. Technol. 12(1):39-47. ISSN 1808-7035. The concentrations of six trace metals $(\mathrm{Pb}, \mathrm{Zn}, \mathrm{Cu}, \mathrm{Cr}, \mathrm{Ni}$ and $\mathrm{Cd})$ in fish, water and sediment samples from Kubanni River located in Zaria, Northern Nigeria, were investigated. The River receives agricultural runoff and municipal wastewaters, and is utilized for drinking, fishing and irrigation. Some water quality characteristics, the fractionation of trace metals in the River sediments, the risk to water column contamination and the levels of the six trace metals in Clarias gariepinus and Oreochromis niloticus samples were evaluated. Except ammonia (mean $0.72 \pm 0.31 \mathrm{mgL}^{-1}$ ), all the River water quality characteristics studied were below the recommended drinking water standards by World Health Organization (WHO), the European Union (EU) and Federal Environmental Protection Agency of Nigeria (FEPA). The average values of $\mathrm{Pb}, \mathrm{Zn}, \mathrm{Cu}, \mathrm{Cr}, \mathrm{Ni}$ and $\mathrm{Cd}$ in River Kubanni water were $6.54 \pm 1.88,106.38 \pm 14.75,73.51 \pm 11.57,37.46 \pm 6.52,11.83 \pm 3.90$ and $0.82 \pm 0.37 \mathrm{mg} \mathrm{L}^{-1}$ respectively. These values were below WHO, EU and FEPA limits. Total extractable trace metals from Kubanni River sediments, (Pb, 16.98; $\mathrm{Zn}, 79.12$; $\mathrm{Cu}, 52.43$; $\mathrm{Cr}$, 29.23; $\mathrm{Ni}, 19.94$ and $\mathrm{Cd}, 4.65 \mathrm{mg} \mathrm{Kg}^{-1}$ dry weight) were all below recommended limits. However, there was considerable risk to River water contamination based on the calculated individual trace metal average contamination factors (IACF) obtained for the River sediments from the trace metal sequential extractions. Also, the distribution and concentration of trace metals obtained in liver, gill, muscle and bone of $C$. gariepinus and $O$. niloticus showed that the human health risk for trace metals in muscles of fish were low, but individuals consuming fish livers might be at risk from ingestion of toxic metals at unacceptable concentrations.
\end{abstract}

Keywords: Wastewater, C. gariepinus, O. niloticus, water quality, sequential extraction.

\section{INTRODUCTION}

River water supports many life forms, provides recreation and fishing to communities, and it may also be used for drinking purposes and irrigation. However, contamination of river water systems by trace metals is of major concern and their determination has received great attention since the events of $\mathrm{Hg}$ and $\mathrm{Cd}$ poisoning through fish in Minamata, Japan (Merson et al., 2006)

Sediments are important sinks for various pollutants like trace metals and also play a considerable role in the remobilization of trace metals in aquatic systems under suitable conditions and in interactions between sediment and water column. The release of trace metals from sediments into the water body and consequently fish will depend on the chemical fractionation of metals and other factors such as sediment $\mathrm{pH}$, and the physical and chemical characteristics of the aquatic system (Canavan et al., 2007). Trace metals may distribute in sediments as exchangeable, acid soluble (bound to carbonates), reducible (bound to $\mathrm{Fe} / \mathrm{Mn}$ Oxides and hydroxides), oxidizable (bound to organic matter) and residual (bound to silicates and detrital materials) species. The chemical fractionation of trace metals in sediments can be investigated by carefully employing a selective extraction scheme from the several extraction schemes available in literature.

Fish is a good source of protein and contains omega- 3 fatty acids that help reduce the risk of certain cancers (Paul et al., 2002; Terry et al., 2001) and cardiovascular disease (La Vecchia et al., 2001). Fish consumption is a major route of trace metal exposure for humans (Dougherty et al., 2000), and children are more at risk because of their greater intestinal absorptions (Soghoian, 2008).

Kubanni River originates in the precincts of the Ahmadu Bello University (ABU) Main Campus, Zaria (Northern Nigeria), as a trench in an undulating agricultural land and is fed by a number of tributaries (Fig. 1). A dam, called ABU dam, was created on the River and serves as a source of water for drinking water production by the ABU water works. This River is also utilized for irrigation, fishing and general domestic application. Furthermore, Kubanni River drains the northwest zone of the city of Zaria and receives effluents 
mainly from domestic activity and runoff from intense crop farming in the adjoining lands.

The quality of river water can be judged only by comparing concentrations of various constituents present in the river water. The analysis of fish or sediments of rivers are thus considered bio-indicators on the basis of which levels of trace metals in the river water could be understood (Kebede \& Wondimu, 2004).
There is no data available yet on Kubanni River water quality and the health status of the River. Adverse effects of pollutants are pre-supposed, when their concentrations exceed the maximum permissible limits. This study was, therefore, carried out to (i) determine the water quality characteristics of Kubanni River and assess the risk of Kubanni River water contamination by River sediments; (ii) investigate the chemical

Location of Zaria Town in Kaduna State, Nigeria Map of Africa Showing Nigeria

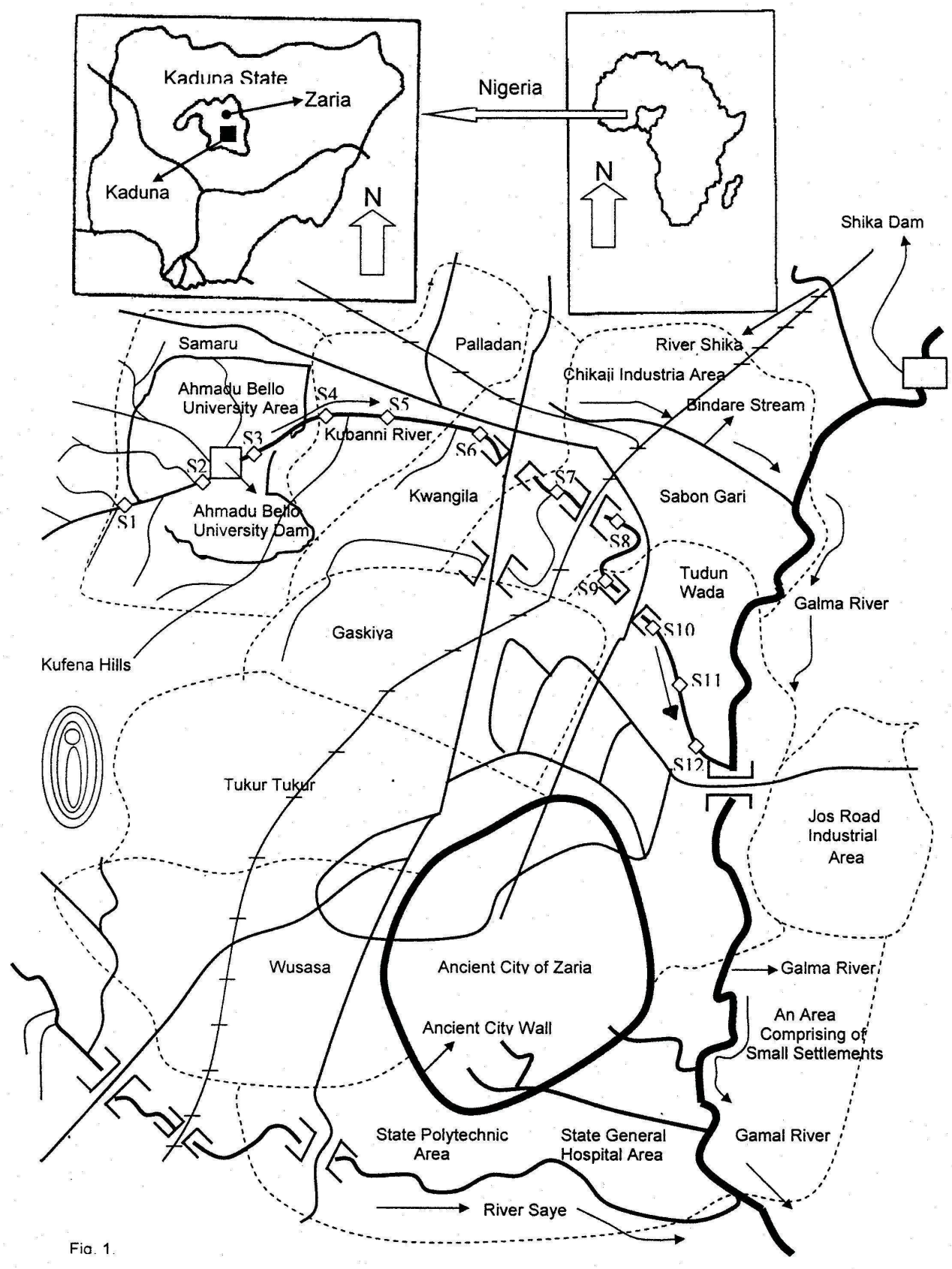

Figure 1 - Map of Zaria Town and location of sampling points S1 - S12 along Kubanni River. 
fractionation of $\mathrm{Pb}, \mathrm{Zn}, \mathrm{Cu}, \mathrm{Cr}, \mathrm{Ni}$ and $\mathrm{Cd}$ in the River sediments because of their environmental implications; and (iii) determine the levels of the $\mathrm{Pb}, \mathrm{Zn}, \mathrm{Cu}, \mathrm{Cr}, \mathrm{Ni}$ and $\mathrm{Cd}$ metals in Clarias gariepinus and Oreochromis niloticus from Kubanni River because of the health implications to human populations consuming fishes from the River.

\section{MATERIALS AND METHODS}

\section{Quality Assurance}

All reagents used in this work were of analytical grade and double distilled water was used throughout the experiment except where indicated otherwise. Washing procedures, sampling container types, chainof-custody procedures, sampling for general parameters and trace metals determinations, sample-holding times and preservation techniques conform to standard methods for water and wastewater analysis (APHA, 1992). Procedural blanks, reagent blanks, preparation of standard solutions under clean laboratory environment, calibration of the atomic absorption spectrometer (Pye Unicam 969) using certified standards and the analysis of calibrated standards after every 10 runs to ensure that the instrument remained calibrated were some of the measures taken during the experiment. Standard Reference Materials (IAEA fishmuscle tissue, SRM № 1646 for sediment and SRM № 1643a for water) procured from the Centre for Energy Research and Training (CERT), Zaria were used to validate the digestion methods and AAS technique. Recovery experiments for the trace metals analyzed using the AAS, were found to be within $98 \pm 5 \%$. Finally, determinations of all parameters were carried out in triplicates per sample of fish tissues, water and sediments to ascertain the precision of the data.

\section{Kubanni River Water Collection and Analysis}

The location of Kubanni River is given in Fig. 1 along with the sampling points for water and sediment samples collected. Sampling was carried out on $17^{\text {th }}$ October, 2006, for fish, water and sediment. River water samples were collected into acid washed polyethylene plastic containers with screw caps and determination of some general parameters and trace metals conform to standard methods (APHA, 1992). Physico-chemical parameters determined include $\mathrm{pH}$, conductivity, alkalinity, phosphate, sulfate, nitrate, chloride, ammonia and trace metals ( $\mathrm{Pb}, \mathrm{Zn}, \mathrm{Cu}, \mathrm{Cr}, \mathrm{Ni}$ and $\mathrm{Cd}$ ). Digests of River water were aspirated into Pye Unicam 969 atomic absorption spectrometer for trace metal determination.

\section{Kubanni River Sediment Collection and Analysis}

Sediment samples were collected using precleaned stainless steel Ekman dredge and immediately placed in plastic bags. Samples were transported to the laboratory and air-dried at room temperature. In order to normalize the variation in grain size distributions, the air-dried sediment samples were ground using acid washed porcelain mortar and pestle. The ground sediment samples were then passed through a $150 \mathrm{~mm}$ sieve and stored in acid washed polyethylene bottles with screw caps at room temperature. Sediment $\mathrm{pH}$ and EC were measured in air-dried samples $(1: 10 \mathrm{w} / \mathrm{v})$ using digital $\mathrm{pH}$ and conductivity meter. Organic matter content was determined by loss on ignition. Exchangeable cations were extracted by $0.1 \mathrm{M} \mathrm{BaCl}_{2}$ and subsequently determined by AAS (Hendershot \& Duquette, 1986). Finally, three sediment sub-samples (one gram each) were subjected to a five step sequential extraction separately using the method of Shrivastava \& Banerjee (2004) as follows:

1. Exchangeable phase: Each sample was shaken at room temperature with $16 \mathrm{~mL}$ of $1 \mathrm{M} \mathrm{Mg}\left(\mathrm{NO}_{3}\right)_{2}$ at $\mathrm{pH} 7.0$ for $1 \mathrm{hr}$, centrifuged and the supernatant decanted and made up to $40 \mathrm{~mL}$ with double distilled water prior to analysis.

2. Oxidizable phase (Bound to organic matter): residue from $1+10 \mathrm{~mL} \mathrm{H}_{2} \mathrm{O}_{2} 8.8 \mathrm{ML}^{-1}+6 \mathrm{~mL} \mathrm{HNO}_{3} 0.02 \mathrm{ML}^{-1}$, was shaken for $5+1 \mathrm{hr}$ at $98^{\circ} \mathrm{C} .10 \mathrm{~mL} \mathrm{CH}_{3} \mathrm{COONH}_{4} 3.5$ $\mathrm{ML}^{-1}$ was added as an extracting agent, centrifuged and supernatant made up to $40 \mathrm{~mL}$ with distilled water prior to analysis.

3. Acid soluble phase (Bound to carbonates): $25 \mathrm{~mL}$ of $0.05 \mathrm{M} \mathrm{Na}_{2}$ EDTA was added to the residue from 2, shaken for $6 \mathrm{hr}$ and centrifuged. The supernatant was decanted and made to $40 \mathrm{~mL}$ with distilled water prior to analysis.

4. Reducible phase (Bound to Fe/Mn oxides and hydroxides): residue from $3+17.5 \mathrm{~mL} \mathrm{NH} \mathrm{NH}_{2} \mathrm{OH} \cdot \mathrm{HCl} 0.1$ $\mathrm{ML}^{-1}+17.5 \mathrm{~mL} \mathrm{CH}_{3} \mathrm{COONH}_{4} 3.5 \mathrm{ML}^{-1}$, shaken for $4+$ $1 \mathrm{hr}$ at $98^{\circ} \mathrm{C}$. Extracted with $10 \mathrm{~mL} \mathrm{CH}_{3} \mathrm{COONH}_{4} 3.5$ $\mathrm{ML}^{-1}$, shaken for $1 \mathrm{hr}$, centrifuged, the supernatant was decanted and made up to $40 \mathrm{~mL}$ with distilled water prior to analysis.

5. Residual phase (Bound to silicates and detrital materials): residue from 4 was digested using aqua regia/ hydrofluoric acid $\left(\mathrm{HCl}-\mathrm{HNO}_{3} / \mathrm{HF}\right)(0.35: 12 \mathrm{w} / \mathrm{v}$ sediment/ solution ratio) in acid digestion Teflon cup. It was dry ashed for $2 \mathrm{hr}$ and evaporated to dryness. The residue was diluted to $40 \mathrm{~mL}$ with distilled water prior to analysis.

After each successive extraction, the samples were centrifuged at $4500 \mathrm{rpm}$ for $15 \mathrm{~min}$ (Legret et al., 1988). The supernatants were removed with pipette and 
filtered with Whatman No. 42 filter paper. The residue was washed with deionized water followed by vigorous hand shaking and then followed by $15 \mathrm{~min}$ of centrifugation before the next extraction. The volume of rinsed water was kept to a minimum to avoid excessive solubilization of solid materials. Finally, the extracts collected were analyzed using AAS to determine the concentrations of $\mathrm{Pb}, \mathrm{Zn}, \mathrm{Cu}, \mathrm{Cr}, \mathrm{Ni}$ and $\mathrm{Cd}$ metals.

\section{Fish Collection and Analysis}

Five samples of Clarias gariepinus and Oreachromis niloticus each, the most common types of fish in Kubanni River and widely consumed, were caught with fishing net. The fish samples obtained were kept on ice in the field and transported to the laboratory. In the laboratory, fish weights and lengths were taken and samples were frozen until the time for analysis. The methods of Hodson et al. (1978) and APHA (1992) were used to determine levels of $(\mathrm{Pb}, \mathrm{Zn}, \mathrm{Cu}, \mathrm{Cr}$, Ni and Cd) trace metals in fish tissues as follows: Fish liver, gill, muscle and bone were weighed out using an acidwashed, pre-weighted dry crucible. The tissues were oven-dried at $60^{\circ} \mathrm{C}$ for $48 \mathrm{hr}$, ground and ashed at $450^{\circ} \mathrm{C}$ for $12 \mathrm{hr}$ when white ash was formed. The ash was then dissolved in double distilled water and digestion of the samples was carried out based on the methods of APHA (1992) using conc. $\mathrm{HNO}_{3}$. The levels of $\mathrm{Pb}, \mathrm{Zn}, \mathrm{Cu}, \mathrm{Cr}$, $\mathrm{Ni}$ and $\mathrm{Cd}$ in digests were then determined using the AAS. To check the accuracy of the methodology used for fish, spiked liver and muscle tissue samples were passed through the same analytical process used for the fish tissue samples. The spike recovery and precision were found to be within $96 \pm 3$.

\section{RESULTS AND DISCUSSIONS}

\section{Water Quality Results}

Table 1 shows some water quality parameters of Kubanni River, reference freshwater values and other published values on rivers in Nigeria and other countries. The $\mathrm{pH}$ of Kubanni River was found to be $8.14 \pm 0.43$, suggesting that the River was alkaline. Also, the mean conductivity of the River was $197.1 \pm 12.5 \mu \mathrm{Scm}^{-1}$, which is lower than the mean conductivity values reported for two alkaline Rivers (Kocacay River and Gökmendere Stream) in Turkey (Colak et al., 2003). Total alkalinity of $30.58 \pm 6.61 \mathrm{mg} \mathrm{CaCO}_{3} \mathrm{~L}^{-1}$. The trend of occurrence $\left(\mathrm{mgL}^{-1}\right)$ of the major anions studied in the River water followed the order,

$$
\text { Sulfate }>\text { chloride }>\text { nitrate }>\text { phosphate, }
$$

Though $\mathrm{SO}_{4}^{2-}$ anion had higher concentration in the River water than the other anions, its level was about 7 and 2 times lower than the reported mean $\mathrm{SO}_{4}{ }^{2-}$ value for Kocacay River and Gökmendere Stream, respectively. On the other hand, the level of $\mathrm{Cl}^{-}$obtained in this study was higher than the $\mathrm{Cl}^{-}$mean values reported for the latter Rivers and the reference value (8 $\mathrm{mgL}^{-1}$ for Cl) for freshwater (Markert, 1994). The observed level of ammonia in the River water ranged from 0.48 to $1.02 \mathrm{mgL}^{-1}$. Ammonia is very toxic to fish and its presence in high concentration in an aquatic body may be a sign of pollution due to industrial effluents, sewage intrusion or agricultural runoff.

The average values of the metals analyzed in Kubanni River water (Table 1) were higher than the respective reference values $(\mathrm{Pb}, 3 ; \mathrm{Zn}, 5 ; \mathrm{Cu}, 3 ; \mathrm{Cr}, 1$; $\mathrm{Ni}, 0.3$ and Cd, $0.2 \mathrm{mgL}^{-1}$ ) for freshwater (Markert, 1994). The result of this study also indicates that the average concentrations of $\mathrm{Pb}, \mathrm{Zn}, \mathrm{Cu}$ and $\mathrm{Cd}$ in Kubanni River water were consistently lower than the corresponding values reported for New Calabar (Pb, 850; Zn, 6590; $\mathrm{Cu}, 2080 ; \mathrm{Cr}, 50$ and $\mathrm{Cd}, 560 \mathrm{mgL}^{-1}$; Wegwu and Akaninwor, 2006) and Jakara (Pb, 1005-1818; Cu, 2851390 and Cd, 290-310 mgL $^{-1}$; Dike et al., 2004) Rivers in Nigeria as well as those for Tyume (Pb, 21-35; Zn, 97-431; $\mathrm{Cu}$, trace-387; Ni, 201-1777 and Cd, 30-44 mgL1 ; Awofolu et al., 2005) and Umtata (Pb, 240-1110; Zn, 70-120; $\mathrm{Cu}, 100-530$ and $\mathrm{Cd}, 10-260 \mathrm{mgL}^{-1}$; Fatoki et al., 2002, 2004) Rivers in South Africa. The levels of these metals $(\mathrm{Pb},<0.1 ; \mathrm{Cu}, 6.1 ; \mathrm{Ni}, 1.1$ and $\mathrm{Cd}, 0.34$ $\mathrm{mgL}^{-1}$ ) for Watarase River, Japan (Ohmichi et al., 2006), were lower than the mean levels for Kubanni River water. Except for ammonia, all mean values of the water quality constituents studied in the River water were below their respective WHO (1993), EU (1998) and FEPA (1991) drinking water standards. However, $\mathrm{Pb}, \mathrm{Zn}, \mathrm{Cu}$, and $\mathrm{Cd}$ levels exceeded the mean background dissolved metal concentrations in African rivers values (CIFA, 1994)). The reported mean background dissolved metal concentration in African rivers in $\mathrm{g} \mathrm{L} \mathrm{L}^{-1}$ were as follows: $\mathrm{Pb}(3), \mathrm{Zn}(20), \mathrm{Cu}(7)$ and $\mathrm{Cd}(0.02)$.

\section{Chemical Fractionation of Trace Metals in Kubanni River Sediments}

The results of the chemical fractionation of trace metals in Kubanni River sediments and some physicochemical characteristics of the sediments are shown in Table 2. The study reveals that the River sediments were alkaline in nature with an average $\mathrm{pH}$ of $9.65 \pm 0.42$. The organic matter and electrical conductivity were found to be $10.35 \pm 2.04 \%$ and $0.35 \pm 0.09 \mathrm{mScm}^{-1}$, respectively. Also, the CEC determined by the sum of $0.1 \mathrm{M} \mathrm{BaCl}_{2}$ exchangeable cations was found to be $114.72 \mathrm{mg} / 100 \mathrm{~g}$ and Ca was the dominant exchangeable cation (53.24 \pm 13.84$)$.

The data obtained by the sequential extraction procedure indicates the following trace metal distribution pattern: 
Braz. J. Aquat. Sci. Technol., 2008, 12(1):39-47.

Table 1 - Mean $( \pm S D)$ of selected water constituents of Kubanni River and other rivers published.

\begin{tabular}{|c|c|c|c|c|c|c|c|c|}
\hline A. Physico-chemical Parameters & $\mathrm{pH}$ & $\begin{array}{l}\text { Conductivity } \\
\left(\mu \mathrm{S} \mathrm{cm}^{-1}\right)\end{array}$ & $\begin{array}{l}\text { Total alkalinity } \\
\left(\mathrm{mg} \mathrm{CaCO}_{3} \mathrm{~L}^{-1}\right)\end{array}$ & $\begin{array}{l}\text { Phosphate } \\
\left(\mathrm{mg} \mathrm{L}^{-1}\right)\end{array}$ & $\begin{array}{l}\text { Sulfate } \\
\left(\mathrm{mg} \mathrm{L}^{-1}\right)\end{array}$ & $\begin{array}{l}\text { Nitrate } \\
\left(\mathrm{mg} \mathrm{L}^{-1}\right)\end{array}$ & $\begin{array}{l}\text { Chloride } \\
\left(\mathrm{mg} \mathrm{L}^{-1}\right)\end{array}$ & $\begin{array}{c}\text { Ammonia } \\
\left(\mathrm{mg} \mathrm{L}^{-1}\right)\end{array}$ \\
\hline $\begin{array}{l}\text { This work } \\
\text { Reference values for Freshwater }{ }^{a}\end{array}$ & $8.14 \pm 0.43$ & $197.1 \pm 12.5$ & $30.58 \pm 6.61$ & $2.91 \pm 1.08$ & $32.45 \pm 7.35$ & $6.28 \pm 2.45$ & $26.05 \pm 4.15$ & $0.72 \pm 0.31$ \\
\hline Kocacay River, Turkey ${ }^{{ }^{\prime}}$ & $8.20-8.36$ & $865-924$ & & & $219.7-265.4$ & & $7-12$ & \\
\hline Gökmendere Stream, Turkey ${ }^{\mathrm{b}}$ & 8.35 & 626 & & & 65.4 & & 17 & \\
\hline WHO (1993) limits* & $6.5-8.5$ & 250 & & & 500 & 50 & 250 & \\
\hline EU (1998) limits* ${ }^{*}$ & & 250 & & & 250 & 50 & 250 & 0.50 \\
\hline FEPA (1991) limits ${ }^{c}$ & $6.5-9.2$ & & & & 150 & 50 & 200 & 0.50 \\
\hline B. Trace metals & $\begin{array}{c}\mathrm{Pb} \\
\left(\mu \mathrm{g} \mathrm{L}^{-1}\right)\end{array}$ & $\begin{array}{c}\mathrm{Zn} \\
\left(\mu \mathrm{gL}^{-1}\right)\end{array}$ & $\begin{array}{c}\mathrm{Cu} \\
\left(\mu \mathrm{gL}^{-1}\right)\end{array}$ & $\begin{array}{c}\mathrm{Cr} \\
\left(\mu \mathrm{g} \mathrm{L}^{-1}\right)\end{array}$ & $\begin{array}{c}\mathrm{Ni} \\
\left(\mu \mathrm{g} \mathrm{L}^{-1}\right)\end{array}$ & $\begin{array}{c}\mathrm{Cd} \\
\left(\mu \mathrm{g} \mathrm{L}^{-1}\right)\end{array}$ & & \\
\hline This work & $6.54 \pm 1.88$ & $106.38 \pm 14.75$ & $73.51 \pm 11.57$ & $37.46 \pm 6.52$ & $11.83 \pm 3.90$ & $0.82 \pm 0.37$ & & \\
\hline Reference values for fresh water ${ }^{a}$ & 3 & 5 & 3 & 1 & 0.3 & 0.2 & & \\
\hline Tyume River, S/Africa ${ }^{d}$ & $21-35$ & $97-431$ & trace -387 & & $201-1777$ & $30-44$ & & \\
\hline Umtata River, S/Africa ${ }^{\mathrm{B}}$ & $240-1110$ & $70-120$ & $100-530$ & & & $10-260$ & & \\
\hline Umtata River, S/Africa ${ }^{\dagger}$ & & $19-161$ & & & & $2-7$ & & \\
\hline New Calabar River, Nigeria ${ }^{9}$ & 850 & 6590 & 2080 & 50 & & 560 & & \\
\hline Watarase River, J apan ${ }^{\mathrm{h}}$ & $<0.1$ & & 6.1 & $<0.5\left(\mathrm{Cr}^{6+}\right)$ & 1.1 & 0.34 & & \\
\hline Jakara River, Nigeria ${ }^{i}$ & $1005-1818$ & & $285-1390$ & & & $290-310$ & & \\
\hline WHO (1993) limits" & 10 & 3000 & 2000 & 50 & 20 & 3 & & \\
\hline EU (1998) limits* & 10 & & 2000 & 50 & 20 & 5 & & \\
\hline FEPA (1991) limits ${ }^{c}$ & & 5000 & 1500 & & & & & \\
\hline
\end{tabular}

WHO(1993)/EU(1998) drinking water standards retrieved from: http://www.lenntech.com/WHO-EU-water-standards.htm; a Market (1994); ${ }^{b}$ Colak et a.l (2003); c Ohmichi et al. (2006); ${ }^{d}$ Awofolu et al. (2005); ${ }^{e}$ Fatoki et al. (2002); ${ }^{\dagger}$ Fatoki et al. (2004); ${ }^{g}$ Wegwu, and Akaninwor (2006); ' Ohmichi et al. (2006); ' Dike et al. (2004).

$\mathrm{Pb}$ : residual $>$ reducible $>$ acid soluble $>$ exchangeable $>$ oxidizable

Zn: residual $>$ oxidizable $>$ reducible $>$ acid soluble $>$ exchangeable

Cu: residual $>$ acid soluble $>$ oxidizable $\approx$ exchangeable $>$ reducible

Cr: residual $>$ oxidizable $>$ reducible $\approx$ exchangeable $>$ acid soluble

$\mathrm{Ni}$ : residual $>$ oxidizable $>$ reducible $>$ exchangeable $>$ acid soluble

Cd: residual $>$ reducible $>$ oxidizable $>$ acid soluble $>$ exchangeable

The non-residual fraction, for all the trace metals, contained more than $37 \%$ of the total extractable metals. All the trace metals, except $\mathrm{Cr}$, were mostly concentrated in the non-residual fractions and reflects the greater tendency of the metals to become available to water column. The study also showed that the sedimentary matrix (residual phase) of the River sediments contained significant fractions of the trace metals. The residual fraction represents metals largely embedded in the crystal lattice of the sediments and should not be available for remobilization except under very harsh conditions. $\mathrm{Pb}$ and $\mathrm{Cd}$ were largely associated with residual and reducible species in the sediments. Fe/Mn oxides (reducible phase) exist as nodules, concretions, cement between particles, or as coating on particles and are excellent trace element scavengers (Jenne, 1968). On the other hand, the oxidizable fraction of $\mathrm{Pb}$ is only $2.6 \%$, in agreement with the fact that alkaline $\mathrm{pH}$ condition doesn't favor the sorption of $\mathrm{Pb}$ by organic matter in sediments (Baruah et al., 1996). Cu existed mostly as residual and acid soluble species. The acid soluble fraction is influenced by $\mathrm{pH}$ and the observed $\mathrm{pH}$ of the sediments was 9.65 , which doesn't favor the release of metals into water column from this fraction. Lastly, $\mathrm{Zn}, \mathrm{Cr}$ and $\mathrm{Ni}$ existed mostly as residual and oxidizable forms. Under oxidizing conditions, metals present in both natural organic matter and living organisms may be remobilized into the aquatic environment. $\mathrm{Zn}, \mathrm{Cr}$ and $\mathrm{Ni}$ removal requires strong acid condition and may not therefore, be available for remobilization into water column since sediments are alkaline.

Total extractable trace metals from Kubanni River sediments, their individual average contamination factors (IACF) and other global published values for river sediments are presented in Table 3 . The data obtained shows that the trend of occurrence of the trace metals in the River sediments was: $\mathrm{Zn}>\mathrm{Cu}>\mathrm{Cr}>\mathrm{Ni}>\mathrm{Pb}>$ $\mathrm{Cd}$. The values got in this study for these metals were higher than the corresponding values $(\mathrm{Pb}, 0.040-0.067$; Zn, 0.080-0.491; Cu, 0.082-0.496;; Ni, 0.401-0.981 and $\mathrm{Cd}$, trace-0.005 $\mathrm{mgkg}^{-1}$ ) for Tyume River (Awofolu et al., 2005) and Calcasieu River/Lake ((Pb, 9.90; Zn, 35.6; $\mathrm{Cu}, 6.91 ; \mathrm{Cr}, 19.1$ and $\mathrm{Cd}, 0.98$ mgkg $^{-1}$; Berk, 1990). However, the levels of $\mathrm{Pb}(43)$ and $\mathrm{Zn}\left(122 \mathrm{mgkg}^{-1}\right)$ reported by Ellaway et al. (2005) for sediments of Yarra River/Estuary (Australia) were higher than the corresponding Kubanni River values. Table 3 also shows the calculated individual average contamination factors (IACF) for the six trace metals analyzed in Kubanni River sediments. The IACF for each metal in the River was calculated from the result of the fractionation study by dividing the sum of the first four fractions (i.e. the exchangeable, carbonate bound, Fe/Mn oxides and hydroxides forms and the oxidizable forms) by the residual fraction for the River and reflects the risk of contamination of a water body by a pollutant. The higher the levels of the mobilizable fractions (i.e. exchangeable, acid soluble, reducible and oxidizable trace metals) in the sediments, the higher the potential risk to River water contamination by River sediment. The remobilization of 
Uzairu et al.: Trace metal in river Kubanni, Nigeria.

Table 2 - Chemical fractionation of trace metals in Kubanni River sediments and some physico-chemical characteristics of the sediments.

\begin{tabular}{|c|c|c|c|c|c|c|c|c|c|c|}
\hline $\begin{array}{l}\text { A. Physico-chemical } \\
\text { Parameters }\end{array}$ & $\mathrm{pH}$ & $\begin{array}{c}\mathrm{EC} \\
\left(\mathrm{mS} \mathrm{cm}^{-1}\right)\end{array}$ & $\begin{array}{c}\text { Organic matter } \\
(\%)\end{array}$ & $\begin{array}{c}\text { Ex-Na } \\
\text { (mg per 100g } \\
\text { dry weight) }\end{array}$ & $\begin{array}{c}\text { Ex-K } \\
\text { (mg per } \\
100 \mathrm{~g} \text { dry } \\
\text { weight) }\end{array}$ & $\begin{array}{l}\text { Ex-Mg } \\
\text { (mg per } \\
100 \mathrm{~g} \text { dry } \\
\text { weight) }\end{array}$ & $\begin{array}{l}\text { Ex-Ca } \\
\text { (mg per } \\
100 \mathrm{~g} \text { dry } \\
\text { weight) }\end{array}$ & $\begin{array}{c}\text { Ex-Fe } \\
\text { (mg per } \\
100 \mathrm{~g} \text { dry } \\
\text { weight) }\end{array}$ & $\begin{array}{l}\text { Ex-Mn } \\
\text { (mg per } \\
100 \mathrm{~g} \text { dry } \\
\text { weight) }\end{array}$ & $\begin{array}{l}\sum_{\text {cations }} \\
\text { (mg per } \\
100 \mathrm{~g} \mathrm{dry} \\
\text { weight) }\end{array}$ \\
\hline & $9.65 \pm 0.42$ & $0.35 \pm 0.09$ & $10.35 \pm 2.04$ & $9.54 \pm 1.98$ & $\begin{array}{c}26.80 \pm \\
2.67 \\
\end{array}$ & $\begin{array}{c}20.73 \pm \\
4.51\end{array}$ & $\begin{array}{c}53.24 \pm \\
13.84 \\
\end{array}$ & $\begin{array}{c}3.02 \pm \\
0.51\end{array}$ & $1.40 \pm 0.36$ & 114.72 \\
\hline $\begin{array}{l}\text { B. Trace metal fraction } \\
\text { ( } \mathrm{mg} \mathrm{Kg}^{-1} \text { dry weight) }\end{array}$ & Exchangeable & $\begin{array}{l}\text { Oxidizable } \\
\text { (Bound to } \\
\text { organic } \\
\text { matter) }\end{array}$ & $\begin{array}{l}\text { Acid soluble } \\
\text { (Bound to } \\
\text { carbonates) }\end{array}$ & $\begin{array}{l}\text { Reducible } \\
\text { (Bound to } \\
\text { Fe/Mn oxides } \\
\text { \& hydroxides) }\end{array}$ & $\begin{array}{c}\text { Residual } \\
\text { (Bound to } \\
\text { silicates \& } \\
\text { detrital } \\
\text { materials) }\end{array}$ & $\%$ & $\begin{array}{l}\text { Non- } \\
\text { residual }\end{array}$ & $\%$ & $\begin{array}{c}\text { Total } \\
\text { extractable }\end{array}$ & \\
\hline $\mathrm{Pb}$ & $1.63 \pm 0.29$ & $0.44 \pm 0.20$ & $2.67 \pm 0.90$ & $4.71 \pm 1.03$ & $7.53 \pm 2.48$ & 44.35 & 9.45 & 55.65 & 16.98 & \\
\hline $\mathrm{Zn}$ & $5.43 \pm 0.93$ & $15.80 \pm 3.00$ & $11.26 \pm 1.74$ & $12.92 \pm 1.43$ & $\begin{array}{c}33.71 \pm \\
4.10\end{array}$ & 42.61 & 45.41 & 57.39 & 79.12 & \\
\hline $\mathrm{Cu}$ & $5.39 \pm 0.92$ & $5.82 \pm 1.31$ & $12.76 \pm 2.40$ & $3.48 \pm 0.74$ & $\begin{array}{l}24.98 \pm \\
4.15\end{array}$ & 47.64 & 27.45 & 52.36 & 52.43 & \\
\hline $\mathrm{Cr}$ & $2.75 \pm 0.61$ & $3.82 \pm 0.85$ & $1.54 \pm 0.41$ & $2.80 \pm 1.03$ & $\begin{array}{l}18.32 \pm \\
3.17\end{array}$ & 62.68 & 10.91 & 37.32 & 29.23 & \\
\hline $\mathrm{Ni}$ & $2.04 \pm 0.80$ & $4.72 \pm 1.63$ & $1.85 \pm 0.47$ & $3.90 \pm 1.51$ & $7.43 \pm 2.11$ & 37.26 & 12.51 & 62.74 & 19.94 & \\
\hline $\mathrm{Cd}$ & $0.20 \pm 0.07$ & $0.65 \pm 0.28$ & $0.49 \pm 0.16$ & $1.14 \pm 0.40$ & $2.17 \pm 1.05$ & 46.67 & 2.48 & 53.33 & 14.65 & \\
\hline
\end{tabular}

Note: (i) Non-residual fraction is the sum of exchangeable, oxidizable, acid soluble and reducible fractions.

(ii) Total extractable trace metal is the sum of all five fractions for the metal.

(iii) All data reported as mean with one standard deviation (SD).

Table 3 - Total extractable trace metals from Kubanni River sediments, their individual contamination factors (ICF) in the River and published mean sediment values in some countries ( $\mathrm{mg} \mathrm{Kg}^{-1}$ dry weight).

\begin{tabular}{|c|c|c|c|c|c|c|c|c|}
\hline \multirow[t]{2}{*}{$\begin{array}{l}\text { Trace } \\
\text { metal }\end{array}$} & \multirow[t]{2}{*}{$\begin{array}{l}\text { This } \\
\text { work }\end{array}$} & \multirow{2}{*}{$\begin{array}{l}\text { Yarra River } \\
\text { Australia } \\
\text { (Ellaway et } \\
\text { al.,2005) }\end{array}$} & \multirow{2}{*}{$\begin{array}{l}\text { Yarra estuary } \\
\text { Australia } \\
\text { (Ellaway et } \\
\text { al.,2005) }\end{array}$} & \multirow{2}{*}{$\begin{array}{c}\text { Calcasieu } \\
\text { River/Lake, } \\
\text { LA, USA } \\
\text { (Berk et al., } \\
\text { 1990) }\end{array}$} & \multirow[t]{2}{*}{$\begin{array}{c}\text { Tyume River } \\
\text { S/Africa } \\
\text { (Awofolu et al., 2005) }\end{array}$} & \multirow[t]{2}{*}{$\mathrm{IACF}^{\mathrm{C}}$} & \multicolumn{2}{|c|}{$\begin{array}{l}\text { Sediment Quality } \\
\text { Guidelines }\left(\mathrm{mgKg}^{-1}\right)\end{array}$} \\
\hline & & & & & & & LELs $^{\mathrm{a}}$ & $S Q S^{b}$ \\
\hline $\mathrm{Pb}$ & 16.98 & 43 & 375 & 9.90 & $0.040-0.067$ & 1.26 & 31 & 450 \\
\hline $\mathrm{Zn}$ & 79.12 & 122 & 447 & 35.6 & $0.080-0.491$ & 1.35 & 120 & 410 \\
\hline $\mathrm{Cu}$ & 52.43 & 64 & 106 & 6.91 & $0.082-0.496$ & 1.10 & 16 & 390 \\
\hline $\mathrm{Cr}$ & 29.23 & & & 19.1 & & 0.60 & 26 & 260 \\
\hline $\mathrm{Ni}$ & 19.94 & & & & $0.401-0.981$ & 1.68 & 16 & \\
\hline $\mathrm{Cd}$ & 4.65 & & & 0.98 & trace -0.005 & 1.14 & 0.6 & 5.1 \\
\hline
\end{tabular}

${ }^{\text {a } L E L s: ~ L o w e s t ~ l e v e l s ~ i n ~ p r o v i n c i a l . ~ S e d i m e n t ~ q u a l i t y ~ g u i d e l i n e s ~ b y ~ t h e ~ O n t a r i o ~ M i n i s t r y ~ o f ~ E n v i r o n m e n t ~ a n d ~ E n e r g y . ~}$

'SQS: Sediment quality standards used as sediment quality goal for Washington State sediments (http://www.ecy.wa.gov/PROGRAMS/ $\mathrm{tcp} / \mathrm{smu} /$ sed-_Chem.htm).

${ }^{c} \mathrm{ACF}=\mathrm{Sum}$ of ( exchangeable, oxidizable, acid soluble and reducible) fractions/residual fraction for the River.

trace metals from the River sediment into water column will be affected by factors such as $\mathrm{pH}$, chemical forms of the trace metals, and physico-chemical characteristics of the water column. The IACF values found were generally significant, with Ni posing the highest risks to River water contamination. Cr posed the lowest risk to water contamination followed by $\mathrm{Cu}$, $\mathrm{Cd}, \mathrm{Pb}$ and $\mathrm{Zn}$.

Currently, Nigeria has set no guideline values on the levels of trace metals in sediments of freshwaters. With the view to making preliminary evaluation of the risks of contamination of Kubanni River sediments by trace metals, comparison was made with sediment quality standards of other countries. For example, all the six trace metals extracted from Kubanni River sediments were lower than the corresponding values of Sediment Quality Standards for Washington State (SQS). However, $\mathrm{Cu}, \mathrm{Cr}, \mathrm{Ni}$ and $\mathrm{Cd}$ were higher than the Ontario (Canada) Ministry of Environment and Energy Provincial Sediment Quality Guidelines Lowest Effect Levels (LELs).

\section{Trace Metals in Kubanni River Fish Samples}

The mean values of the six trace metals (mg $\mathrm{kg}^{-1}$ wet weight) evaluated in pooled liver, gills, muscle and bone of $C$. gariepinus and $O$. niloticus collected from Kubanni River are shown in Table 4. The distribution of the trace metals varied as follows: 
Braz. J. Aquat. Sci. Technol., 2008, 12(1):39-47.

Table 4 - Mean ( $\pm \mathrm{SD}$ ) of trace metals ( $\mathrm{mg} \mathrm{Kg}^{-1}$ wet weight) in Kubanni River fish samples.

\begin{tabular}{|c|c|c|c|c|c|c|c|}
\hline Fish & $\begin{array}{c}\text { Tissue } \\
\text { type }\end{array}$ & $\mathrm{Pb}$ & $\mathrm{Zn}$ & $\mathrm{Cu}$ & $\mathrm{Cr}$ & $\mathrm{Ni}$ & $\mathrm{Cd}$ \\
\hline \multirow{4}{*}{$\begin{array}{l}\text { Clarias } \\
\text { gariepinus }\end{array}$} & Liver & $0.28 \pm 0.10$ & $49.56 \pm 8.21$ & $19.31 \pm 2.55$ & $12.50 \pm 1.51$ & $1.05 \pm 0.36$ & $0.21 \pm 0.08$ \\
\hline & Gill & $0.12 \pm 0.04$ & $20.05 \pm 3.74$ & $1.87 \pm 0.15$ & $2.78 \pm 0.30$ & $2.41 \pm 0.28$ & $0.13 \pm 0.02$ \\
\hline & Muscle & $0.04 \pm 0.01$ & $4.92 \pm 1.50$ & $0.24 \pm 0.02$ & $0.40 \pm 0.03$ & $0.92 \pm 0.06$ & $0.02 \pm 0.00$ \\
\hline & Bone & $0.09 \pm 0.03$ & $21.90 \pm 4.13$ & $0.16 \pm 0.02$ & $1.08 \pm 0.22$ & $1.27 \pm 0.11$ & $0.04 \pm 0.01$ \\
\hline \multirow{4}{*}{$\begin{array}{l}\text { Oreochromis } \\
\text { niloticus }\end{array}$} & Liver & $0.76 \pm 0.13$ & $65.72 \pm 7.76$ & $40.11 \pm 6.00$ & $7.85 \pm 1.42$ & $3.21 \pm 0.24$ & $0.40 \pm 0.10$ \\
\hline & Gill & $0.24 \pm 0.11$ & $26.14 \pm 3.28$ & $5.32 \pm 1.47$ & $10.63 \pm 2.74$ & $2.76 \pm 0.18$ & $0.08 \pm 0.02$ \\
\hline & Muscle & $0.02 \pm 0.00$ & $7.61 \pm 1.83$ & $1.15 \pm 0.38$ & $0.68 \pm 0.14$ & $0.03 \pm 0.00$ & $0.02 \pm 0.01$ \\
\hline & Bone & $0.15 \pm 0.06$ & $16.49 \pm 2.51$ & $3.49 \pm 0.75$ & $0.47 \pm 0.09$ & $1.13 \pm 0.08$ & $0.03 \pm 0.01$ \\
\hline FAO $\left(\mathrm{mg} \mathrm{Kg}^{-1}\right)^{\mathrm{a}}$ & & 0.5 & 30 & 30 & & & 0.5 \\
\hline $\begin{array}{l}\text { Health criteria } \\
\left(\mathrm{mg} \mathrm{Kg}^{-1}\right)^{\mathrm{b}}\end{array}$ & & 4 & 480 & 120 & 8 & & \\
\hline $\begin{array}{l}\text { CCFAC ML } \\
\left(\mathrm{mg} \mathrm{Kg}^{-1}\right)^{\mathrm{c}}\end{array}$ & & 0.2 & & & & & 0.5 \\
\hline
\end{tabular}

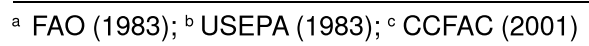

Clarias gariepinus: $\mathrm{Pb}, \mathrm{Cr}$ and $\mathrm{Cd}$ : liver $>$ gill $>$ bone $>$ muscle; Zn: liver > bone > gill > muscle; Cu: liver > gill $>$ muscle > bone; and $\mathrm{Ni}$ : gill > bone > liver > muscle.

Oreachromis niloticus: $\mathrm{Pb}, \mathrm{Ni}, \mathrm{Zn}$ and $\mathrm{Cu}$ : liver > gill > bone > muscle; Cr: gill > liver > bone > muscle; and Cd: liver > gill > bone H" muscle.

Generally, the levels of trace metals in the liver and gills irrespective of the type of fish were higher than the results obtained for bone and muscle. The higher level of trace metals in the liver relative to other tissues may be attributed to the high coordination of metallothionein protein with the metals (Friberg et al., 1971). In addition, the liver is the principal organ responsible for the detoxification, transportation, and storage of toxic substances and it is an active site of pathological effects induced by contamination (Evans et al., 1993). The gills perform the function of respiration and are directly in contact with water and pollutants that may be present in water. Thus, the concentrations of trace metals in gills reflect the concentration of trace metals in the waters where the fish lives (Romeo et al., 1999). Annune \& lyaniwura (1993) also reported that the liver of $O$. niloticus and $C$. gariepinus accumulated more $\mathrm{Zn}$ and $\mathrm{Cd}$ than other tissues. Similarly, the low levels of trace metals in muscle tissues of both $C$. gariepinus and $O$. niloticus observed in this study agree with the findings of Brooks \& Rumsey (1974), Badsha \& Goldspink (1982), Oladimeji \& Offem (1989), and Annune
\& lyaniwura (1993) who studied the bioaccumulation of trace metals in several fish species including $C$. gariepinus and $O$. niloticus.

The mean levels of $\mathrm{Pb}, \mathrm{Zn}, \mathrm{Cu}$, and $\mathrm{Cd}$ in muscle, gill and bone of both $C$. gariepinus and $O$. niloticus were below the health criteria established by the United States Environmental Protection Agency (USEPA, 1983) for human health risk for carcinogens, Food and Agriculture Organization (FAO, 1983) maximum limits and Codex Committee on Food Additives and Contaminants maximum levels (CCFAC, 2001). However, pooled mean $\mathrm{Pb}, \mathrm{Zn}, \mathrm{Cu}$ and $\mathrm{Cr}$ levels in livers of the two fish species analyzed exceeded the US EPA, FAO and CCFAC guidelines in general. Thus, there may be some concern for individuals consuming fish livers.

\section{CONCLUSION}

The health status of Kubanni River with respect to water quality, risk to water column contamination by trace metals in the River sediments and quality of fish caught from the River for human consumption were evaluated in this study. Apart from ammonia content (mean $0.72 \pm 0.31 \mathrm{mg} \mathrm{L}^{-1}$ ), River water quality characteristics investigated were all below the recommended drinking water standards by World Health Organization (WHO), European Union (EU) and Federal Environmental Protection Agency of Nigeria (FEPA). 
Risk to water contamination by metals was, however, significant based on the calculated individual trace metal average contamination factors (IACF) obtained for the River sediments from the trace metal fractionation study. Also, risks from consumption of fish muscles were low since the mean levels of all the trace metals in Clarias gariepinus $(\mathrm{Pb}, 0.04 \pm 0.01 ; \mathrm{Zn}, 4.92 \pm 1.50 ; \mathrm{Cu}, 0.24 \pm$ 0.02 ; Cr, $0.40 \pm 0.03$; Ni, $0.92 \pm 0.06$ and $\mathrm{Cd}, 0.02 \pm$ $\left.0.00 \mathrm{mg} \mathrm{Kg}^{-1}\right)$ and Oreochromis niloticus $(\mathrm{Pb}, 0.02 \pm$ $0.00 ; \mathrm{Zn}, 7.61 \pm 1.83 ; \mathrm{Cu}, 1.15 \pm 0.38 ; \mathrm{Cr}, 0.68 \pm 0.14$; $\mathrm{Ni}, 0.03 \pm 0.00$ and $\mathrm{Cd}, 0.02 \pm 0.01 \mathrm{mg} \mathrm{Kg}^{-1}$ ) muscles were below the corresponding USEPA, FAO and CCFAC permissible limits. However, individuals consuming fish livers may face considerable risk from ingestion of toxic metals at unacceptable concentrations. Finally, this work may provide valuable database for future research on Kubanni River.

\section{REFERENCES}

Annune, P.A. \& lyaniwura, T.T. 1993. Accumulation of two trace metals in tissues of freshwater fishes, Oreachromis niloticus and Clarias gariepinus. J. Aquat. Food Prod. Technol., 2(3): 5-8.

APHA (American Public Health Association, American Water Works Association and Water Pollution Control Federation). 1992. Standard methods for the examination of waters and wastewaters. $18^{\text {th }} \mathrm{ed}$. Washington D.C. 1.18-3.6pp

Awofolu, O.R.; Mbolekwa, Z.; Mtshemla, V. \& Fatoki, O.S. 2005. Levels of trace metals in water and sediment from Tyume River and its effects on an irrigated farmland. Water SA, 31(1): 87-944.

Badsha, K.S. \& Goldspink, C.R. 1982. Preliminary observations on the heavy metal content of four species of freshwater fishes in N.W. England. J. Fish Biol. 21: 251-267.

Baruah, N.K.; Katoky, P.; Bhattacharyya, K.G. \& Borah, G.C. 1996. Metal speciation in Jhanji River sediments. Sci. Total Environ. 193: 1-12.

Berk, J. N.; Ramelow, G. J.; Thompson, R. S.; Mueller, C. S.; Webre, C. L.; Young, J. C. \& Langley, M. P. 1990. Heavy metal content of sediments in the Calcasieu River/Lake complex, Louisiana, Hydrobiologia, 192: 149-165.

Brooks, R.A. \& Rumsey, D. 1974. Heavy metals in some New Zealand commercial sea fishes. NZ J. Mar. Freshwater Res. 8(1):155-166.

Canavan, R.W.; Van cappellen, P.; Zwolsman, J.J.G.; Van den Berg, G.A. \& Slomp, C.P. 2007. Geochemistry of Trace Metals in a freshwater sediment: Field results and diagnetic modeling. Sci. Total Environ. 381: 263-279
CCFAC (Codex Committee on Food Additives and Contaminants). 2001. Report of the $33^{\text {rd }}$ sessionDraft maximum levels for lead and cadmium. FAO/ WHO Food Standards Programme. Retrieved on 02/ 05/07 from: www.fao.org/docrep/meeting/005/ y0474E/y0474E00.htm

CIFA (Committee for Inland Fisheries of Africa). 1994. Review of pollution in the African aquatic environment, Calamari, D.; Naeve, H., eds., Technical paper number 25, Food and Agriculture Organization (FAO), Rome. 118p.

Colak, M. ; Gemici, U. \& Tarcan, G. 2003. The effects of colemite deposits on the arsenic concentrations of soil and ground water in lgdeköy - Emet, Kütahya, Turkey. Water, Air, and Soil Pollution 149: 127-143.

Dike, N.I.; Ezealor, A.U. \& Oniye, S.J. 2004. Concentrations of $\mathrm{Pb}, \mathrm{Cu}, \mathrm{Fe}$ and $\mathrm{Cd}$ during the dry season in River Jakara, Kano, Nigeria. Chemcl. J. Chem. Soc. (Nig.) 2004: 78-81. 391

Dougherty, C.P.; Henricks, H.S.; Reinert, J.C.; Panyacosit, I.; Axelrad, D.A. \& Woodruff, T.J. 2000. Dietary Exposures to Food Contaminants Across the United States. Environmental Research. 8: 170185.

Ellaway, M.; Hart, B.T. \& Beckett, R. 2005. Trace metals in sediments from Yarra River. Australian J. Mar. Freshwater Res. 33 (5): 761-778. 398

EU. 1998. Drinking water Standards. Retrieved on 02/ 05/07 from: http://www.lenntech.com/WHO'sdrinking-water-standards.htm

Evans, D.W.; Doo, D.K. \& Hanson, P. 1993. Trace metal concentration in fish livers: implications of variation with fish size in pollution monitoring. Mar. Pollut. Bull. 26: 329-334.

FAO (Food and Agriculture Organization). 1983. Compilation of legal limits for hazardous substances in fish and fishery products, FAO Fishery Circular No. 463: 5-100 pp.

Fatoki, O.S.; Awofolu, O.R. \& Benthe, B. 2004. Cadmium in Umtata River and the Associated Health Impact of on Rural Communities Who Are Primary Users of Water from the River. Water SA. 30(4): 507-514.

Fatoki, O.S.; Lujiza, N. \& Ogunfowokan, A.O. 2002. Trace metals pollution in Umtata River. Water SA 28(2):183-190. 413

FEPA (Federal Environmental Protection Agency of Nigeria). 1991. Guidelines and Standards for Environmental Pollution Control in Nigeria. 54-55 pp.

Friberg, L.; Piscator, M. \& Northberg, G. 1971. Cadmium in the environment. Cleveland: Chemical Rubber $\mathrm{G}$. 91-125

Hendershot, W.H. \& Duquette, M. 1986. A simple barium chloride method for determining cation exchange 
capacity and exchangeable cations. Soil Sci. Soc. Am. J. 50: 605-608.

Hodson, P.V.; Blunt, B.R. \& Spry, D.J. 1978. Chronic toxicity of water - borne and dietary lead to rainbow trout Salmo gairdneri $(\mathrm{R})$ in Lake Ontario water. Water Res. 12: 869-878.

Jaleel, T.; Jaffar, M. \& Ashraf, M. 1993. Levels of Selected Heavy Metals in Commercial Fish from Five Fresh Water Lakes of Pakistan. Toxicol. Env. Chem. U.K. 33: 133-140.

Jenne, E.A. 1968. Trace inorganics in water. Adv. Chem. Ser. 73: 337-387.

Kebede, A. \& Wondimu, T. 2004. Distribution of Trace elements in muscle and organs of Tilapia, Oreochromis niloticus, from lakes Awassa and Ziway, Ethiopia. Bull. Chem. Soc. Ethiopia, 18 (2): $119-130$

La Vecchia, C.; Chaatenoud, L. ; Altieri, A. \& Tavari, A. 2001. Nutrition and Health: Epidemiology of Diet, Cancer aand Cardiovascular Disease in Italy. Nutr. Metabol. Cradiov. Dis. 11: 10-15.

Legret, M.; Diver, L. \& Juste, C. 1988. Movement and speciation of heavy metals in a soil amended with sewage sludge containing large amount of cadmium and nickel. Water Res. 22(8): 953-969.

Markert, B. 1994. Inorganic chemical finger printing of the environment; reference freshwater a useful tool for comparison and harmonization of analytical data in freshwater chemistry. Fresenius Z. Anal. Chem. 349: 697-702.

Merson, M.H.; black, R.E. \& Mills, A. 2006. International Public Health: Diseases, Programs, Systems and Policies. Jones and Bartlett Pulishers. 426p

Ohmichi, K.; Seno, Y.; Takahashi, A.; Kojima, K.; Miyamoto, H.; Ohmichi, M.; Matsuki, Y. \& Machida, K. 2006. Recent heavy metal concentrations in Watarase Basin around Ashio mine. Journal of Health Science 54(4): 465-468.
Oladimeji, A.A. \& Offem, B.O. 1989. Toxicity of water borne lead to Clarias laser, Oreachromis niloticus, Chironomus tetans and Benacus sp. Water, Air, and Soil Pollution. 44: 191-201.

Paul, T.; Alicja, W.; Harri, V. \& Elisabete, W. 2002. Fatty Fish Consumption Lowers the Risk of Endometrial Cancer: A Nationwide Case-Control Study in Sweden. Cancer Epidemiol. Biom. Prevent. 11: 143145.

Romeo, M.; Siau, Y.; Sidoumou, Z. \& Gnassia-Barelli, M. 1999. Heavy metal distribution in different fish species from the Mauritania coast. Sci. Total Environ. 232: 169 - 175.

Shrivastava, S.K. \& Banergee, D.K. 2004. Speciation of metals in sewage sludge and sludge-amended soils. Water, Air, and Soil Pollution. 152: 219-232.

Soghoian, S. 2008. Toxicity of Heavy metals. Retreved on 12/05/08 from: www.emedicine.com/EMERG/ topic237.htm

Terry, P.; Lichtenstein, P.; Feychting, M.; Ahlbom, A. \& Wolk, A. 2001. Fatty Fish Consumption and Risk of Prostate Cancer. Lancet. 357: 1764-1766.

US EPA (United States Environmental Protection Agency). 1983. Methods for Chemical Analysis of Water and Wastewater, EPA Report 600/4-79-020, Office of water, Cincinnati, Ohio. 89-111

Wegwu, M.O. \& Akaninwor, J.O. 2006. Assessment of heavy metal profile of the New Calabar River and impact on juvenile Clarias gariepinus. Chemistry and Biodiversity 3(1): $79-87$.

WHO.1993. Drinking water standards retrieved on 10/ 11/06 from: http://www.lenntech.com/WHO'sdrinking-water-standards.htm 